\title{
Our surgical procedure in acut thrombosis of stent graft using in treatment of pseudoaneurysm developing in popliteal anastomosis region of previous cross-over composite sequential femoro-popliteal bypass
}

\author{
K Ergunes*', E Celik, O Gokalp, H Iner, H Cakır, A Gurbuz \\ From 23rd World Congress of the World Society of Cardio-Thoracic Surgeons \\ Split, Croatia. 12-15 September 2013
}

\section{Background}

Occlusion of femoro-popliteal bypass graft represents a limb and life-threatening condition requiring emergency intervention.

\section{Methods}

A 66-year-old man was admitted to our hospital on November 11, 2012. He had a painful, pulseless, and cold below-knee in right lower extremity. He had previous right cross-over composite sequential femoropopliteal bypass. Angiography showed acute occlusion of cross-over composite femoro-popliteal bypass graft and stent graft used in treatment of pseudoaneurysm developing in popliteal anastomosis region of this graft. Proximal EPTFE graft was occluded with thrombus in arteriography.

\section{Results}

Thrombectomy was performed with the 5F Fogarty balloon catheter and excessive thrombus was extracted. A thrombo-embolectomy was performed to the distal of popliteal artery, but thrombus was not detected in this region. The patient was performed a new interposition saphenous vein graft between the proximal EPTFE graft and distal popliteal artery. The patient received lowmolecular weight heparin in postoperative period. He received warfarin and acetylsalicylic acid in follow-up.
Right lower extremity pulses were palpable in postoperative period. Right lower extremity had good function in follow-up at 6 months.

\section{Conclusions}

We showed importance of saphenous vein graft bypass and thrombectomy in a case of having acute occlusion of cross-over composite sequential femoro-popliteal bypass.

Published: 11 September 2013

\section{doi:10.1186/1749-8090-8-S1-P116}

Cite this article as: Ergunes et al:: Our surgical procedure in acut thrombosis of stent graft using in treatment of pseudoaneurysm developing in popliteal anastomosis region of previous cross-over composite sequential femoro-popliteal bypass. Journal of Cardiothoracic Surgery 2013 8(Suppl 1):P116.

* Correspondence: kazimergunes@yahoo.com

Izmir Katip Celebi University Ataturk Training and Research Hospital

Department of Cardiovascular Surgery, Izmir, Turkey

() 2013 Ergunes et al; licensee BioMed Central Ltd. This is an Open Access article distributed under the terms of the Creative Commons 